\title{
Migrant Workers' Child Care Style in Cilacap District
}

DOI: https://doi.org/10.47175/rissj.v1i3.95

\section{| Urip Tri Wijayanti ${ }^{1}$ | Dwi Purwaningsih² |}

\author{
1,2 National Population and \\ Family Planning Board \\ (BKKBN), Center Java \\ Province, Indonesia
}

haidar1602@yahoo.co.id

\begin{abstract}
The Migrant workers in Cilacap District are dominated by women who are married, so that the care of the children is carried out by the father. This research aims to examine the father's parenting. This research uses a qualitative approach. It uses Purposive selection to find the informants. The Informants include father, wife/ mother, secondary family (grandfather, grandmother, and siblings). Data were collected by interview, observation and documentation. The results of the study were two kinds of care, some were delegated to secondary families. For example grandparents or other relatives and some were cared for by their husbands/ fathers. However, in general the care is delegated to secondary families. The reason is because the husband/father does not have parenting experience. The parenting pattern applied by secondary families / grandparents applies permissive and democratic parenting. Then for those who are cared for by their husbands / fathers themselves apply a democratic parenting pattern. Where parents are warm and affectionate to children. Parents, especially fathers, explain why children should not do something. For care for adolescents, care is done by the husband/ father himself. The pattern of parenting that is applied uses permissive and democratic patterns. BKKBN recommendation needs to carry out parenting training for fathers, so that female migrant families do not delegate care to secondary families KEYWORDS

Parenting style; children; migrants workers; women.
\end{abstract}

\section{INTRODUCTION}

Toddler period is the golden age period because at the age of 0-2 years the child's brain development reaches $80 \%$. At this time it is a very good opportunity to develop aspects of the child physically, emotionally, socially and intellectual knowledge. (BKKBN, 2017). Therefore, the golden age must not be wasted, parents must nurture, guide and guide optimally. So that children can grow and develop according to their growth period.

Being a parent is not something easy, there is no school that teaches parenting. Parenting lessons are self-taught. Starting from parenting lessons while in the womb to being born and growing into adolescents. Parents must also be able to interact reciprocally with their children. This is necessary so that the interactions that are built are harmonious interactions. It is not surprising that good parenting methods for children will provide good role models for children in the future (Santrock, 2007). In essence, the parenting style carried out by parents to children will shape the child's personality in socializing in social life (Hurlock, 2010).

Parenting is the process of educating, teaching character, self-control and shaping the desired behavior (BKKBN, 2017). Referring to this concept, it can be understood that parenting includes adults as educators, there are parenting styles and the output is in the form of expected behavior. The expected behavior is of course good behavior. Good 
parenting produces children with good personalities, so that they become intelligent adults who have good speaking skills, are confident, independent, responsible, thoughtful, not easily affected by bad environments, and are able to face challenges in their future lives (BKKBN, 2017). For that, it requires parents who are able to do good, loving and quality parenting.

Parenting is the responsibility of both parents. Ideally, both parents help each other to raise their children. The results of Rotenberg's research (lestari, 2012) show that mothers play a role in forming beliefs about the importance of trust, while fathers play a role in shaping trusting behavior. These results show that the two of them are mutually exclusive even though they perform different functions.

But in reality, not all parents are able to fulfill it. There are families who completely surrender to the father figure. This is because of the agreement in the family where the mother has to earn a living for her family. Economic problems make mothers have to work abroad, the hope that they will be able to change family life for the better makes them willing to leave their children and husbands in Indonesia. This fact appears in the families of female migrant workers in Central Java Province, especially Cilacap District.

Cilacap District is a district in Central Java which contributes the largest number of migrant workers and is ranked 4th nationally. BNP2TKI noted that there were more than ten thousand migrant workers who came from Cilacap district. BNP2TKI noted that the number of migrant workers from Cilacap tended to fluctuate, from 2017 to 2018 there was an increase in the number of migrant workers by $15.8 \%$, then in 2019 it decreased by $2.6 \%$, but when compared to 2017 there was still an increase of $12.8 \%$ (table 1).

Table 1. Placement of Indonesian Migrant Workers by District/ City, 2017 to 2019

\begin{tabular}{|l|l|l|l|l|}
\hline No & District/ City & $\mathbf{2 0 1 7}$ & $\mathbf{2 0 1 8}$ & $\mathbf{2 0 1 9}$ \\
\hline 1 & INDRAMAYU & 17.658 & 22.144 & 23.360 \\
\hline 2 & EAST LOMBOK & 15.232 & 12.832 & 12.284 \\
\hline 3 & CIREBON (DISTRICT) & 10.185 & 11.829 & 12.188 \\
\hline 4 & CILACAP & 10.177 & 11.785 & 11.480 \\
\hline 5 & PONOROGO & 9.157 & 10.043 & 9.665 \\
\hline 6 & BLITAR & 8.520 & 9.189 & 9.154 \\
\hline 7 & CENTER LOMBOK & 9.802 & 9.569 & 8.957 \\
\hline 8 & EAST LAMPUNG & 5.469 & 6.891 & 8.069 \\
\hline 9 & MALANG & 8.370 & 8.839 & 7.928 \\
\hline 10 & KENDAL & 7.495 & 7.812 & 7.650 \\
\hline 11 & TULUNGAGUNG & 6.173 & 7.108 & 7.104 \\
\hline 12 & SUBANG & 7.859 & 7.602 & 6.694 \\
\hline 13 & BAYUWANGI & 5.176 & 6.132 & 6.343 \\
\hline 14 & BREBES & 4.823 & 5.995 & 6.247 \\
\hline 15 & MADIUN & 4.689 & 4.913 & 4.982 \\
\hline 16 & KEDIRI & 3.625 & 4.145 & 4.027 \\
\hline 17 & BANYUMAS & 3.799 & 4.112 & 3.886 \\
\hline 18 & PATI & 3.425 & 3.700 & 3.824 \\
\hline 19 & KARAWANG & 3.104 & 3.586 & 3.749 \\
\hline 20 & WEST LOMBOK & 4.421 & 4.212 & 3.518 \\
\hline 21 & MAJALENGKA & 2.856 & 3.346 & 3.393 \\
\hline 22 & CENTER LAMPUNG & 2.444 & 3.057 & 3.324 \\
\hline 23 & GROBOGAN & 2.728 & 3.207 & 3.248 \\
\hline 24 & MAGETAN & 2.786 & 2.989 & 2.975 \\
\hline 25 & TRENGGALEK & 2.668 & 3.005 & 99.541 \\
\hline 26 & LAINNYA & 100.258 & 105.598 & 99.541 \\
\hline & & 262.899 & 283.640 & 276.553 \\
\hline \multicolumn{1}{|c|}{ Total } & & & \\
\hline
\end{tabular}

Data period is written in January $07^{\text {th }}, 2020$

Source: Data Report on the Placement and Protection of Indonesian Migrant Workers, BNP2TKI 
Based on data from Cilacap District Manpower Office, migrant workers are dominated by women. In fact, the number is three times the number of male migrant workers (Figure 1). The number of female migrant workers is an interesting thing to study when it comes to childcare because from 2018 and 2019 there were approximately 10,007 families who carried out care without the presence of the mother.

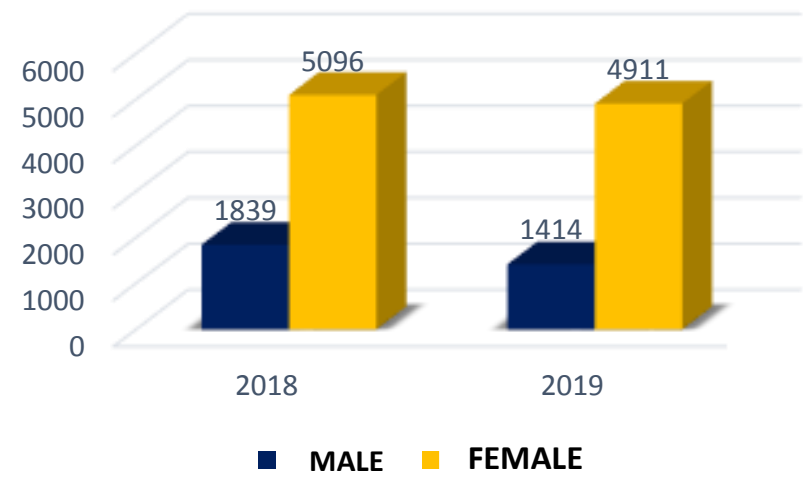

Figure 1. Number of Migrant Workers from Cilacap District by Gender in 2018 and 2019, Cilacap District Manpower Office

The study of the care of migrant workers is not new, Mega Andhika Sutiana et al (Mega Andhika Sutiana et al, 2018) that the parenting patterns applied by the parents of TKW children are not absolute using authoritarian, democratic, or permissive parenting, basically the parenting style is more mixed. Lestari (Lestari, 2018) there are three parenting patterns that are applied to authoritative (democratic) care, authoritarian (authoritarian) tends to be tough and strict. If the child does not obey or behaves wrongly, the child will get punishment, as a result the child has difficulty establishing social relationships. The permissive parenting applied by single parents displays the type of parent who is less assertive and tolerates inappropriate children's behavior, thus encouraging the child to act out of control and social norms. Meanwhile, the perception of education and religion of every single parent applies authoritarian parenting (authoritarian).

Larry Winget (Larry, 2019) in his book your kids are your own fault states that there are five bases for parenting, namely communication, involvement, education, discipline and punishment. In his book, communication is the first basis for parenting children, with two rules, namely parents must (a) be able to speak, because according to Larry the cause of problems in the family is not from spoken words but rather from unspoken words. (b) willing to listen, effective communication in the family if the child's parents listen to each other's words, to understand the topic of each conversation. According to BKKBN (2017), there are several types of parenting styles used by parents. This type of parenting includes authoritarian/ assertive, permissive, democratic and ignores/ doesn't care about children. Based on the results of research conducted by Diana Baumrind in (Silalahi et al., 2010) that parenting can be classified into 4, namely democratic parenting, authoritarian parenting, permissive parenting and neglect.

Research on the patterns of caring for female migrant workers in Cilacap district has never been conducted. In fact, the results of this study are very useful for the government, especially the agencies/ offices that handle care, so that they are able to make programs that affect parenting so that children continue to grow and develop with appropriate care, even if only done by one party. Therefore, this research aims to examine the care that fathers do to the families of female migrant workers. 


\section{RESEARCH METHODS}

This research uses a qualitative approach. The use of qualitative methods aims to determine the description of childcare for migrant workers' families. This research took place in Cilacap District. The consideration to take this location is because Cilacap district is the district with the largest number of Indonesia workers in Central Java Province and is ranked fourth nationally. These migrant workers are generally married, therefore in the family of female migrant workers there is care that is carried out only by one figure, namely the father without the presence of the mother. This is because the mother has to earn a living for her family. Hopefully, with this uniqueness it is appropriate to conduct a study. The selection of informants in this study was carried out purposively, namely being selected with certain considerations and goals. In accordance with the theme of this study, which examines the parenting patterns of female migrant workers, the informants in this study are the fathers of the family of female migrant workers.

The technique of collecting data by interview, interviewing the father / husband, wife / mother, secondary family (grandfather, grandmother, siblings) in the family of female migrant workers. Then observations were made on the care that the father does in his daily life for his children. Observations were also made on data from the Cilacap District Manpower Office on the number of female migrant workers. Documentation in the form of number of migrant workers in Cilacap District based on district and destination country. The data analysis technique consists of three activities that occur simultaneously, namely data reduction, data presentation, and conclusion drawing. First, all the data obtained from the interviews were collected and then sorted which one was appropriate to answer the problem formulation in this study. Furthermore, it is described in order to get an overview of the parenting patterns that the father does.

\section{RESULT AND DISCUSSION}

In the discussion of parenting, researchers divided into two. First care for toddlers and children and secondly care for adolescents. This distinction is made because based on the results of the study, care for toddlers, children and adolescents is carried out by different actors. For more details, the following is presented.

\section{Care for toddlers and children}

Based on the research results of female migrant workers who have children under five, there are two caregivers. First, there are those who are delegated to their secondary families, for example grandparents or other siblings, secondly, there are those who are cared for by their husbands/ fathers themselves. However, in general the care is delegated to secondary families. The reason for the family to delegate care to the secondary family is because the husband/ father does not have parenting experience. Of course, those who have had parenting experience have. In the results of the research, many families have only one child, so they do not have experience. Delegating care is the best solution so that children stay safe and calm when their mother leaves them. Female migrant workers will feel safe and calm when they leave their children with their parents. As the result of an interview with one of the following migrant workers: 
"As long as I am here (in Taiwan) my child is taken care of by my mother, because if you have experienced caring for me and my younger siblings, while if you are cared for by my husband, I feel calm, because my husband has never had a child ... what will happen when the child is sick, the child is fussy, the child asks for this... just more calm in the mother's care, so here I am also calm at work, looking for money for my child"

Delegating care to secondary families has an impact on the lack of closeness between children and parents. In communication, children often do not want to communicate with their mother and they seem to lack warmth. As the following interview results:

"Lare niku nek bibite bade ngomong, nek lare mboten bolong mboten gelem ngomong " (the child is if the mother wants to talk to her child, if her child doesn't want to do it ... doesn't want to talk).

The closeness that is built is more with the grandmother and grandfather. Meanwhile, in their parenting style, grandmothers are permissive. What the grandchild wants is given with the care of the grandson away from his mother. Grandparents do not apply behavioral boundaries and allow children to do things according to the wishes of the grandchildren. In addition to permissive parenting, grandmothers and grandfathers also apply democratic parenting. They are warm and affectionate to their grandchildren, even their affection exceeds that of their child as a child. This is because grandson is a comfort at dusk. Moreover, seeing the cute behavior of children really treats fatigue due to age. The love given by the grandparents usually causes the child to refuse to obey the father's advice, let alone the distant mother. So that parents sometimes feel that their children are more obedient to grandmothers and grandfathers. Unlike the children who are fully cared for by their father. Dad really did his job to the full. As the following interview results:

"I do everything myself, I cook, wash, and babysit. From the age of 4.5 years, her mother has left to Singapore until now she is in grade 1 of elementary school, my activities are early in the morning to cook after cooking, the children eat and finish studying because I study online, I will accompany them, if she doesn't know she will ask me"

Father is as a figure capable of being an educator in this era of the Covid pandemic. Indeed, during the Covid pandemic 19 parents must be able to become impromptu educators. Because children must learn from home online, this step is taken as a form of breaking the chain of covid 19 transmission that is sweeping the world. This situation requires parents to accompany their sons and daughters. Accompanying children to get their right to learn is a noble role that requires awareness and skills of parents in carrying it out. (Diana, 2020). 
A conducive learning environment accompanied by appropriate assistance from parents will shape children's preferences and habits in learning. Zahrok \& Suarmini, (2018) also stated that the family is one of the most important parts in making children better, one of which is education, the family becomes one of the education centers for children (Alfiana, 2013).

Palkovits (2002) concluded that the involvement of fathers in childcare has several definitions, including: 1 . Involved with all activities carried out by children (McBride \& Mills, 1993). 2. Make contact with children 3. Financial support 4. The number of play activities that are done together. Based on the results of the research, the father has involvement in all parts of childcare. This is because the mother is not present in the care. Fathers are able to carry out parenting roles because they have experience, as shown in the following interview:

"I see this parenting experience from the older siblings who are married to see their daily lives, even though they work closely here. I see oh ... I see ... if the child is abandoned by the mother working how to care for him like that, it happens to our family"

The parenting experience that the father had in his youth became a provision when he was married. There are some fathers who have learned parenting so it is not difficult when they have to care for their own children. Experience according to Siagian (2002) is a whole lesson learned by a person from the events he did during his life. Experience can be obtained by someone directly or indirectly. Siagian (2002) suggests that direct experience is when someone has worked in an organization, then because of something they leave the organization and move to another organization. Meanwhile, indirect experience is an event that is observed and followed by a person in an organization even though the person concerned himself is not a member of the organization in which the observed and followed events occur. In the context of this parenting, the experience obtained by the father is in the category of indirect experience where the father gets it from seeing, feeling and being followed by the care his family did when he was young. This provision is finally applied to his family life today.

Behind the ability of fathers in parenting, there are still things that make children feel less like the following interview results:

"For protest, I already know that her mother is working, only sometimes she says she misses mom ... I usually explain that when I have been on leave, I can go home and for communication, I can use video calls every day, only the difference is that I don't feel what the child feels I can see. from the sign that he misses his mother again "

When a child feels lonely and needs the presence of a mother figure, what the father does is to be warm and affectionate to the child, he is also able to explain to the child that his mother is not together every day with him because he has a goal to start making him happy. Fathers are also able to bring children closer to their mothers, through communication technology, they can still be awakened every day. So that the child does not feel far from his mother. In a context like this, the pattern of parenting that is applied uses a democratic pattern. Where parents are warm and affectionate to children. Parents, 
especially fathers, explain why children should not do something. The father explains the existence of the mother so that the child does not do something, for example demanding that the mother be present at certain events that present parents. Fathers also value the child's ability to make decisions, children's interests, children's opinions and children's personalities. As the following interview results:

"If you have a child in your heart, you follow your parents while your parents do ... follow their wishes as long as they don't endanger or worry your parents, okay ... you're a problem for me"

Children have the freedom to do things as long as they are within reasonable limits. This will encourage children to have the ability to be creative and express their positive ideas. The child feels unfettered by the authoritarian rules of the parents. The results showed that parenting style has a positive relationship with learning motivation (Anggraini, 2014). In other words, parenting style determines the level of student motivation to excel in learning. In other words, parents who apply democratic parenting that provide freedom for their children to be creative, respect children's interests will have a big effect on children's achievement. Children will enjoy learning in their environment. Meanwhile, according to Stanford Dean and Julie Lythcott-Haims, children who lack freedom from their parents are more prone to become victims of BULLY at school or their environment. Bullying occurs due to a lack of communication skills between children and their friends (Ramadhani, 2017)

\section{Care for Unmarried Teen / 10-24 years old}

Based on, the results of research, female migrant workers who have teenagers, in terms of caring for their husbands/ fathers themselves. This is because the care for adolescents is easier than toddlers. Toddlers must understand how to care for children in detail from physical care, how children grow according to their age, provide balanced nutrition, etc. while caring for adolescents is more in the direction of how parents direct not to do things that are prohibited and intense supervision is not until falling for negative actions that can ruin his future.

The parenting pattern applied by the father in the care of adolescents uses permissive and democratic patterns. Parents do not impose behavioral boundaries and allow children to do things according to their own wishes but still democratic, namely parents explain why children should not do something. Something that has a negative impact. The form of freedom given by parents in terms of association is as follows:

"The second child graduated from high school, the child is too cheerful, thanks God there has never been a problem with the environment. Thank God, there are lots of friends who often play ... in my interactions, I don't limit the important thing.

Freedom in association does encourage children to have many friends. However, that freedom must be controlled, because many cases of freedom of association have made teenagers fall into drugs, free sex, etc. As the results of research by Siti Suhaida, H. Jamaluddin Hos, Ambo Upe (2018) stated that promiscuity has an impact on decreasing student achievement, dropping out of school and getting pregnant outside of marriage.

The results showed that the parenting style which was carried out by only one parent had a positive or negative impact. The positive impact of adolescents is to be independent, social and diligent. But the negative side in terms of education is not wanting to go to a higher level of schooling and this promiscuity is caused by a lack of attention from parents. 


\section{Hope about upbringing}

In general, the informants wanted attention from the government, for female migrant care families who had to do incomplete care. This attention is expressed in a parenting training program for fathers. As the following interview results:

\section{"For me, there needs to be training for fathers about childcare"}

Providing understanding to parents, especially for fathers, in female migrant care families is important. So that the father is able to carry out the parenting role that should be done together with his wife. So that children can still get good care and avoid behavioral disorders from parents who are unable to provide care and ensure optimal growth and development of children. This effort is commonly known as parenting training, which is a program to change or improve children's care and parenting skills (2010). The definition of parenting according to Brooks (2011) is the process or the state of being a parent, meanwhile Morrison18 defines parenting as the process of developing and utilizing the knowledge and skills appropriate to planning for, creating, giving birth to, rearing and / or providing care for offspring or a process of developing and utilizing the right knowledge and skills to plan, create, give birth, raise and or provide care for children.

The California Evidence-Based Clearinghouse [CEBC] \& Centers for Disease Control and Prevention in Roshonah (2019) states that parenting activities can be delivered individually or in groups in homes, classrooms, or other settings. Execution arrangements can be made flexibly. The media used can be in the form of face-to-face or online, including lecture methods, direct instruction, discussion, video playback, strategy, or other formats.

\section{CONCLUSION}

Based on the results of research on childcare for the families of female migrant workers, there are two types of care, some are delegated to secondary families, for example, grandparents or other relatives and some are cared for by their husbands/ fathers themselves. However, in general the care is delegated to secondary families. The reason for the family to delegate care to the secondary family is because the husband/ father does not have parenting experience. The parenting pattern applied by secondary families/ grandparents applies permissive and democratic parenting. Then for those who are cared for by their husbands / fathers themselves apply a democratic parenting pattern. Where parents are warm and affectionate to children. Parents, especially fathers, explain why children should not do something.

For care for adolescents, care is done by the husband/ father himself. The parenting pattern applied by the father in the care of adolescents uses permissive and democratic patterns.

BKKBN recommendation needs to carry out parenting training for fathers, so that female migrant families do not delegate care to secondary families.

\section{REFERENCES}

Alfiana, E. (2013). Pola Asuh Orang Tua Terhadap Anak Dalam Keluarga Pada Bidang Pendidikan Di Dusun Pandanan Desa Pandanan Kecamatan Wonosari Kabupaten Klaten. Universitas Negeri Yogyakarta In Skripsi. https://doi.org/10.1016/j.bbapap.2013.06.007.

Anggraini, R. (2014). Hubungan Pola Asuh Orang Tua dengan Motivasi Belajar Siswa. Jurnal Ilmiah Pendidikan Bimbingan dan Konseling, 2 (1): 25-33. 
BKKBN. (2017). Menjadi Orang Tua Hebat Dalam Mengasuh Anak 0-6 Tahun. Jakarta: BKKBN.

Brooks, J. (2011). The Process of Parenting. New York: Mc. Graw Hill.

Diana, R. (2020). Peran orang tua dalam pendidikan anak di era pandemic covid-19. Yogyakarta: Psikologi UIN Sunan Kalijaga Yogyakarta .

Larry, W. (2019). Your kids are your own faulth. Jakarta: PT MIC.

Lee, A. (2012). Building Bridges With Your Teenagers. Jakarta: Media Komputindo.

Lestari, A. P. (2018). Peran Ayah Sebagai Pengasuh Tunggal Dalam Keluarga Tki Di Desa Kemloko Kecamatan Kranggan Kabupaten Temanggung . Yogyakarta: UIN Sunan Kalijaga.

Mega Andhika Sutiana et al. (2018). Pola Pengasuhan Anak Pada Keluarga TKW Di Kecamatan Srengat. Paradigma. Volume 06 Nomor 01 tahun 2018.

Moleong, L. (1990). Metode Penelitian Kualitatif. Bandung: PT Remaja Rosdakarya.

Palkovitz, R. (2002). Involved fathering and child development: Advancing our understanding of good fathering. In C. S. Tamis-LeMonda \& N. Cabrera (Eds.), Handbook of father involvement: Multidisicplinary perspectives . New Jersey: .

Ramadhani, Y. (2017, August 1). https://tirto.id/ambisi-dan-kekangan-orangtua-berakibatburuk-pada-anak-anak-czyL. Retrieved from https://tirto.id/ambisi-dan-kekanganorangtua-berakibat-buruk-pada-anak-anak-czyL: https://tirto.id/ambisi-dan-kekanganorangtua-berakibat-buruk-pada-anak-anak-czyL.

Roshonah, A. F. (2019). Urgensi Program Pelatihan Parenting dalam Meningkatkan Kemampuan Komunikasi Orangtua dengan Anak. Jurnal Studi Kependidikan dan Keislaman - Vol 5, No. 2 (2019.

Rusidi. (2006). Metodologi Penelitian Elaborasi Pedoman Penulisan Tesis dan Disertasi. Bandung: UNPAD.

Shochib, M. (2010). Orang Tua Dalam Membantu Anak Mengembangkan Displin Diri. Jakarta: PT Rineka Cipta .

Siagian. (2002). Kiat Meningkatkan Produktifitas Kerja. Jakarta: Rineka Cipta.

Silalahi et al. (2010). Keluarga Indonesia: Aspek dan Dinamika Zaman. Jakarta: PT. RajaGrafindo Persada.

Sitti Suhaida et al. (2018). PERGAULAN BEBAS DI KALANGAN PELAJAR (Studi Kasus di Desa Masaloka Kecamatan Kepulauan Masaloka Raya Kabupaten Bomabana). Neo Societa, Vol. 3; No. 2; 2018 ISSN: 2503-359X; Hal. 425-432.

Zahrok, S. \&. (2018). Peran Perempuan Dalam Keluarga. IPTEK Journal of Proceedings Series., https://doi.org/10.12962/j23546026.y2018i5.4422. 